\title{
Rådhuset i Åbenrå
}

Af $H . V$. Gregersen.

Ved indgangen til det 19. århundrede stod det klart for alle Åbenrås borgere, at det meget snart ville blive nódvendigt at opf $\emptyset$ re et nyt rådhus til erstatning for byens gamle, brøstfæeldige, der havde stået helt siden tiden efter den store brand i 1610. I april 1826 blev beslutningen om en ivarksattelse af de lange nærede byggeplaner omsider truffet, men da var der ganske vist også sket noget, som tvang bystyret til at gøre alvor af det påt:ankte rådhusbyggeri.

Allerede 30 år tidligere havde man gjort anstalter til at få et nyt rådhus bygget. Det var dengang, da hele det danske samfund oplevede den florissante tid med gode indtjeningsmuligheder især for skibsfarten, der var Åbenrås livsnerve eller »byens sjæel «, som man gerne udtrykte sig. En del materialer var blevet anskaffet, men så satte Danmarks ulykkelige inddragelse i Napoleonskrigene med ét bom for alle planer om et stort og bekosteligt byggeri. De indk $\phi$ bte materialer blev afhændet, efter sigende til dels bortødet, og lige vidt var man.

Men som årene gik, blev byens rådhus mere og mere brøstfældigt. I julen 1817 måtte man ovenik $\phi$ bet opgive at benytte de dervarende fangselsrum, og byfogeden skulle fra nu af ud til amtsfængslet på Brundlund slot med sine arrestanter. Byens gæid som følge af krigene og de ugunstige konjunkturer $i$ krigsårene derefter tvang dog til stadig udsættelse af det planlagte rådhusbyggeri.

I 1826 mente magistraten imidlertid at kunne forsvare en gennemf $\phi$ relse af de længe narede $\emptyset$ nsker om et nyt rådhus. I de senere år havde Åbenrå genvundet en del af sin gamle handel, hedder det således $i$ magistratens ans $\varnothing$ gning af 5 . april 1826, 
skibsfarten var atter stigende, og byen ville derfor nu være i stand til selv at bære en stor del af omkostningerne.

Og̊ påtrængende n $\varnothing$ dvendigt var byggeriet! Det gamle rådhus kunne nårsomhelst styrte sammen. Bygmester Peter Callesen havde foretaget en grundig undersøgelse af det og påvist, at bjælker og bindingsværk overalt var pilråddent, men værre var det, at murene sank. På vest-, nord- og østsiden drejede det sig om 3-4 tommer, men på sydsiden ud imod den forlængst tilkastede stadsgrav fra middelalderen var muren sunket hele 18 tommer! Endelig var det kendt af alle bystyrets mænd, at man nxppe engang kunne sidde tørt $i$ det eneste anvendelige værelse, for det var så utæt, at der ved kraftig vestenvind opstod stærk træk. Når man kender de lokale forhold og ved, hvorledes rådhuset ligger i læ for vestenvinden bag ved den sydlige udløber af bybanken, vil man forstå, at situationen har været alvorlig. Fodkoldt var der også, klagede man, på grund af de tomme og uopvarmede fængselsceller nedenunder. Byens vise mænd tog derfor med glæde imod borgmester, justitsråd Bendix Schows tilbud om, at fremtidige byråds- og magistratsmøder kunne afholdes i hans statelige, senbarokke borgerhus i Slotsgade, den såkaldte »Gamle Borgmestergård «.

Når Åbenrå magistrat netop i 1826 var blevet ivrig for at fá gang i det længe påtænkte rådhusbyggeri, skyldtes det if $\varnothing$ lge dens ansøgning, at der frembød sig gode muligheder for at skaffe sig materialer til en rimelig pris, fordi badeetablissementet $\gg$ Frederikslyst « (»Friedrichslust») kunne købes, da selskabet, der havde drevet dette foretagende, netop var trådt i likvidation. Den pågæeldende ejendom var f $\phi$ rst blevet opf $\phi$ rt i 1818, og ved en nedrivning ville materialerne derfor kunne finde anvendelse $i$ det planlagte rådhusbyggeri. Det lod sig på den tid lettere gøre, fordi man dengang bandt stenene i kalk.

Badeetablissementet $\gg$ Frederikslyst * var blevet oprettet på fysikus August Wilhelm Neubers initiativ, men de store forventninger, man havde neret til del, var ikke blevet indfriede, og på en generalforsamling den 10 . marts 1826 var det da blevet besluttet at opløse selskabet. Ved en aktietegning var der $\mathrm{i}$ sin tid 


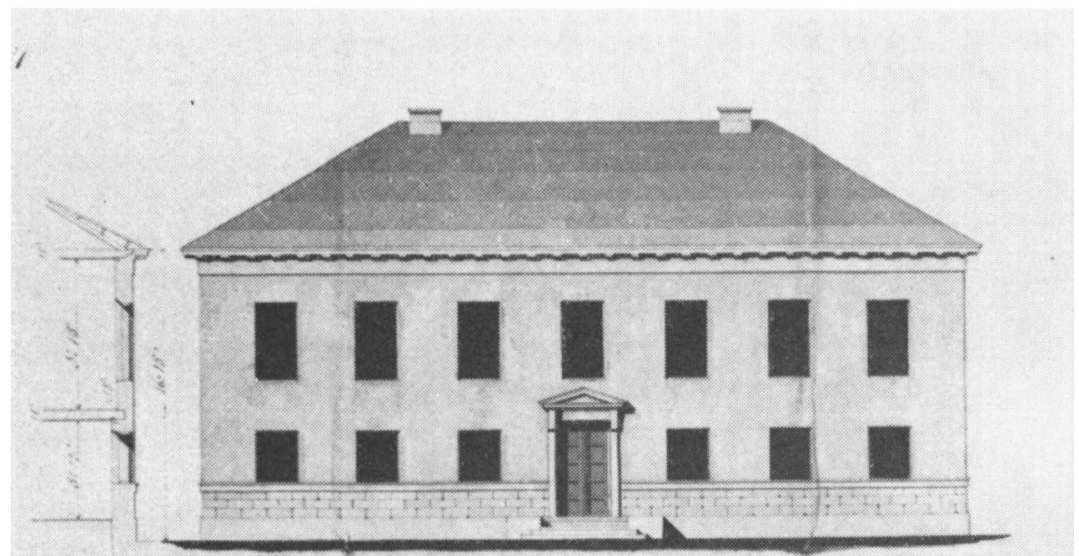

c. F. Hansens forslag nr. 1 (431/2 alen bred).

i selve Åbenrå skaffet 2400 rigsbankdaler, og 2000 rbdl. havde varet kongens bidrag.

Blandt de åbenråske aktionærer var en betydelig del af bystyrets mænd, forst og frenumest borgmester Bendix Schow, senatorerne Hermann Frees og $J$. Lorenzen, samt rảdmxendene $J$. $M$. Habelien og Fr. Andresen. Det er derfor ikke så vanskeligt at gatte sig til, hvorfor byens magistrat nogle få uger efter selskabets likvidation $i$ en ans $\phi$ gning til regeringen om tilladelse til bygning af et nyt rådhus fandt det betimeligt at fremhæve de gode tider for den åbenråske skibsfart! Ved at kombinere afviklingen og nedrivningen af Frederikslyst « med opf $\phi$ relsen af et nyt rådhus reddede Ảbenrås egne aktionærer deres penge, mens eventuelle tab måtte bares af udenbys folk. Bygningen af Åbenrås nuværende rådhus frembyder således et herligt eksemp'el på, hvorledes en lille klike i enevældens dage forstod at udnytte $o g$ forvalte et of entligt hverv til eget bedste.

Den mand, der blev hystyrets faglige garant for det formålstjenlige $i$ en sådan fremgangsmåde, var en af Åbenrås ansete håndværkere, bygmester Peter Callesen, der i sin tid også havde

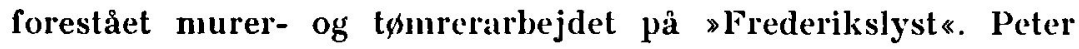
Callesens syn af det gamle rådhus og hans beregninger af omkostningerne til nybyggeriet blev benyttet af magistraten i dens 
skrivelser til regeringen, og det i en sådan grad, at arkitekt $C$. $F$. Hansen, som vi siden skal høre, fandt det besynderligt, at een og samme person både anslog omkostningerne og påtoģ sig arbejdets udf $\phi$ relse, uden at det forinden havde varet udbudt $i$ offentlig licitation.

Men sådan skete det faktisk. Bygmester Peter Callesen anslog materialerne fra $\gg$ Frederikslyst til at vare 4460 rbdl. værd, og byen overtog derefter etablissementet for gaelden, der androg 4320 rbdl. Forsåvidt skulle der vare lale om et fordelagtigt $k \phi b$ for slet ikke at tale om, at både de åbenråske aktionarer og kongen fik indskuddene i det fallerede foretagende dækket. Det var derfor ikke så sært, at regeringens anerkendelse af de trufne dispositioner indtraf i løbet af nogle få måneder, den 23. september 1826 .

For at skafle plads til det nye rådhus, der skulle vare betydeligt større end det gamle, blev bager Jacob Carsten Brohrsgaards ejendom erhvervet for 1280 rbdl. + bankhæftelser [efter statsbankerotten i 1813] på 162 rbdl. Derved opnåede man en byggeplads, der var 62 alen ud mod gaden og 63 alen dyb, mens det gamle rådhus Kun havde målt $29 \frac{1}{2} 2$ alen. 'Til Brohrsgaards hus hørte også have og stald, og det var hensigten at ombygge stalden til sprøjtehus og bolig for vagterne.

Arbejdet med nedrivningen af det gamle rådhus og Brohrsgaards ejendom, samt ombygningen af stalden blev omgående overdraget bygmester Peter Callesen, der kunne anvende de nedbrudte byggematerialer til fundament for det nye rådhus, ligesom jernværk og grundsten fra det gamle rådhus blandt andet kunne blive udnyttet ved indrettelsen af de nye fangselsceller i det planlagte rådhus.

Peter Callesen var således allerede inden selve nybyggeriets godkendelse af regeringen så stærkt engageret, at man ikke godt kunne komme udenom at overlade ham det videre forn $\varnothing$ dne byggearbejde. For lettere at få sagen til at glide efter $\emptyset$ nske hæudede magistraten da også, at Callesens overslag var så rimeligt, at det ikke ville kunne fås bedre $i$ Åbenrå, og det mảtte jo væere $i$ hans egen interesse, at nedbrydningen af de pågældende ejendomme skete så forsigtigt, at materialerne var anvendelige til nybygge- 


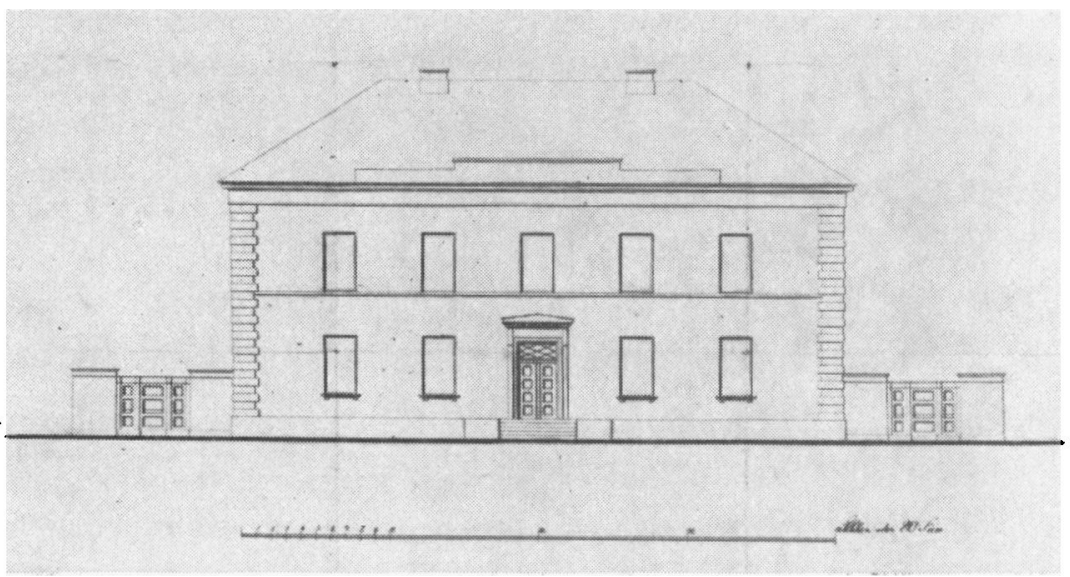

W. F. Megers rids $B$ ('A alen bred).

riet. En udlicitering af arbejdet mătte derfor absolut frarädes, da den blot ville vanskeligg $\phi r e$ byens kontrol med dets udf $\varnothing$ relse. Desuden var ingen andre af byens murere $i$ stand til at påtage sig en sådan entreprise. "Callesen er ikke alene en indsigtsfuld, men også en retskaffen mand, som vil kunne stille beh $\emptyset$ rigs garanti for byggeriets holdbarhed og rigtige udf har en embedsmand i Statholderskabet på Gottorp, hvorfra skrivelsen skulle til videre behandling i Tyske Kancelli i K $\phi$ benhavn, $i$ en randnote ment at burde tilf $\varnothing j e: ~ \bowtie D e t$ lader til, at magistraten ikke rigtigt vil ud med sproget, idet den for enhver pris har villet lade Callesen besørge nedbrydningen af selskabshuset!\&

2: Efter grundens rydning var alt klar til, at man kunne gå i gang med bygningen af det nye rådhus. Peter Callesen udkastede derfor et forel $\phi$ bigt rids over, hvorledes han og magistraten kunne tænke sig opgaven løst. Man kan vel gå ud fra, at han med hensyn til rådhusets ydre har haft det nedbrudte selskabshus $\gg$ Frederikslyst $\ll i$ tankerne, mens dets indre rumfordeling $i$ hovedtrækkene har lignet det hidtidiges. I hvert fald synes han at have foreslået byrådssalen placeret imod vest, hvor den efter de ovenfor nævnte beklagelser over træk forårsaget af vestenvinden tilsyneladende også har været i det nedbrudte rådhus. 
Callesens forel $\phi b i g e$ rids blev af magistraten videresendt til nærmere arkitektonisk udformning hos bygningsinspekt $\varnothing \mathrm{r}$ Wilhelm Friedrich Mleyer, med hrem Callesen åbenbart også tidligerc har haft forbindelse. Det er måske ham, der har haft ansvaret for »Frederikslyst\&s arkitektur. I et brev til Callesen - skrevet på dansk, da Callesen som håndværker ikke tilhørte Åbenrås tyskpragede patriciat - anviser Meyer, hvor han kan skaffe sig noget Segeberger kalk til det forestående storbyggeri, og hele tonen i hrevet tyder på en vis fortrolighed.

I marts 1827 havde Meyer to arkilekttegninger til det nye rådhus færdige, og de gik derefter gennem Statholderskabet til godkendelse i Tyske Kancelli. I begge tilfælde var der tale om en langstrakt bygning $i$ to stokværk, dækket af et afvalmet tag, foran hvilket en lav fronton med indskriften: »MED LOV SKAL MAN LAND BYG\& fandtes. Rids A blev imidlertid straks kasseret, da projektet ville blive for stort og bekosteligt. Dets udf $\varnothing$ relse blev af Callesen anslået til at ville andrage 7.900 rbdl., mens rids $B$, hvorefter rådhuset med samme dybde fik en 14 fod kortere front ud imod gaden, starkt anbefaledes. Dets udførelse anslog han til 6.700 rbdl.

Begge Meyers tegninger var gennemf $\phi \mathrm{rt}^{\mathrm{t}}$ symmetriske med hovedd $\phi \mathbf{r}$ i midten af nederste stokværk og to vinduer til hver side. Øverste stokværk havde fem vinduer, der nøje korresponderede med vinduer og $d \phi r$ i nederste stokværk. Men det st $\varnothing r r e$ rids $A$ var udf $\emptyset$ rt med en kraftig, fremspringende midterrisalit, der dog virker noget usammenarbejdet med bygningens hele. Den vandrette virkning er på begge tegninger søggt udformet ved hjælp af et bredt gesimsbånd under taget og et smalt murbånd, der flugter med underkanten af vinduerne i $\emptyset$ verste stokværk. Gennemgående kvaderlisẻner (hjørnerustikker) kanter bygningsværket på begge sider og giver det en tydelig indramning, der navnlig på det mindre rids $B$, hvor den noget umotiverede midterrisalit fra rids $A$ er fjernet, giver et fuldendt indtryk af koncentration.

I Tyske Kancelli, hvortil de åbenråske byggeplaner var indgået, lod man overbygningsdirektør, konferensråd Christian Frederik 


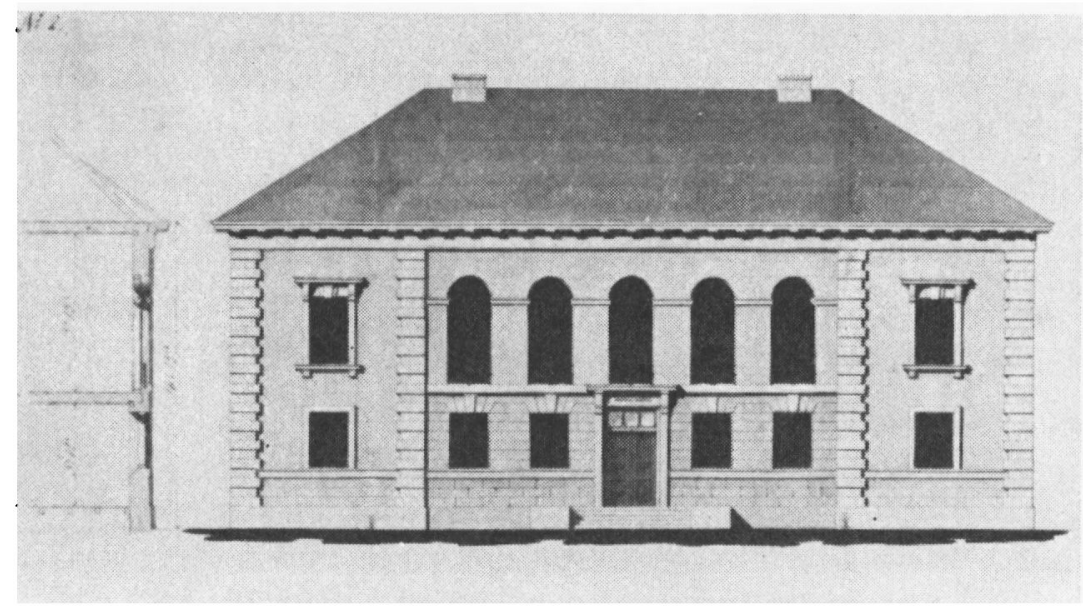

C. F. Hansens forslug nr 2 (4.31, alen bred).

Hansen udtale sig om de foreliggende skitser, og dermed indtrådte en ny fase i det åbenråske rådhusbyggeris historie.

C. F. Hansen, hvis forældre for фvrigt stammede fra Husum, havde på det tidspunkt gennem en menneskealder været det Danske Monarkis f $\phi$ rende arkitekt. Han havde allerede i slutningen af det 18. århundrede vundet sig et navn som bygningsinspekt $\phi r$ for Holsten med bopæl i Altona, hvor en betydelig del af patricierhusene - især i gaden Palmaille - er tegnet af ham. Ved århundredskiftet blev han kaldt til Kobenhavn, hvor han i sin egenskab af overbygningsdirekt $\emptyset r$ prægede bybilledet i nyklassicismens ånd.

I sin udtalelse om de to skitser foretrak $C$. F. Hansen naturligvis straks rids $B$, men fandt, at nederste stokværk burde være lavere, $i$ stedet for $6 \frac{1}{2}$ alen $5 \frac{1}{2}$ alen. Derved ville bygningen vinde $i$ breddevirkning. Uopfordret udarbejdede han derefter to nye forslag, der begge havde samme dybde som på Meyers rids, men var een alen lavere og lidt bredere, nemlig $43 \frac{1}{2}$ alen imod 41 alen på Meyers rids B. Ydermere anbragte C. F. Hansen syv vinduer $i$ $\phi$ verste etage og seks $i$ nederste, grupperet omkring hoveddøren i midten.

C. F. Hansens forslag $\mathrm{nr}, 1$ forekom Åbenrå magistratsmedlem- 
mer noget »einfach «, vel sagtens fordi det stilmæssigt lå nyklassicismen betydeligt nærmere end Meyers rids B (for slet ikke at tale om hans rids A), idet han skabte en kraftigere breddevirkning ved at fjerne kvaderlisénerne eller hjørnerustikkerne på Meyers rids. C. F. Hansen lægger nemlig sjældent så stor vægt på koncentrationen i sine bygningsværker. Den vandrette virkning uddybede han desuden ved hjælp af brede murkvadere mellem sokkelen og gesimsbåndet under den nederste vindueskant, ligesom en tandsnitfrise under taget $i$ forening med et bredt gesimsbånd understreger bygningens bredde. Forslag nr. 1 er således i mange henseender et typisk arbejde af C. F. Hansen. Det virker i bredden, er midtsamlet omkring hovedd $\varnothing r e n$, der dog i overensstemmelse med Meyers rids indrammes af en klassisk trekantgavl og et par pilastre uden udsmykning.

Selv har $C$. F. Hansen åbenbart ikke fundet sit forslag nr. 1 helt tilfredsstillende. Dertil var det $\mathbf{i}$ for $h \varnothing j$ grad kalkeret over en andens arbejde. Han lavede derfor - stadig, hvad der er typisk for manden, på eget initiativ! - et forslag nr. 2, der må anses for at være et langt mere karakteristisk arbejde af denne kunstner. I virkeligheden er der blot tale om en variation af det façadeskema, han tidligere havde anvendt på Metropolitanskolen i K $\varnothing$ benhavn. C. F. Hansens stilpræg havde først og fremmest det antikke Rom og renæssancens Italien til forbillede og $i$ så henseende er hans forslag nr. 2 et typisk eksempel på, hvad han forstod ved nyklassicisme.

Bygningen optræder her delt i tre partier, to sidepartier omkring et bredt midterparti, tydeligt adskilt ved rustika og ved forskellige vinduestyper. Midterpartiet har nemlig $i$ $\phi$ verste etage fem meget h $\varnothing j e$ rundbuede vinduer, mens sidepartierne hver for sig må nøjes med et noget mindre vindue, der er indrammet på samme måde som hovedd $\phi r e n$. Den græske trekantgavl er forsvundet og erstattet af en overligger, der er langt mere karakteristisk for empirens byggestil. I nederste stokværk er vinduerne overalt langt mindre end de tilsvarende ovenover og dertil kom, at midterpartiet i stueetagen er forsynet med kvadret murværk, mens det var tanken, at de фvrige murflader ligesom på de fleste 


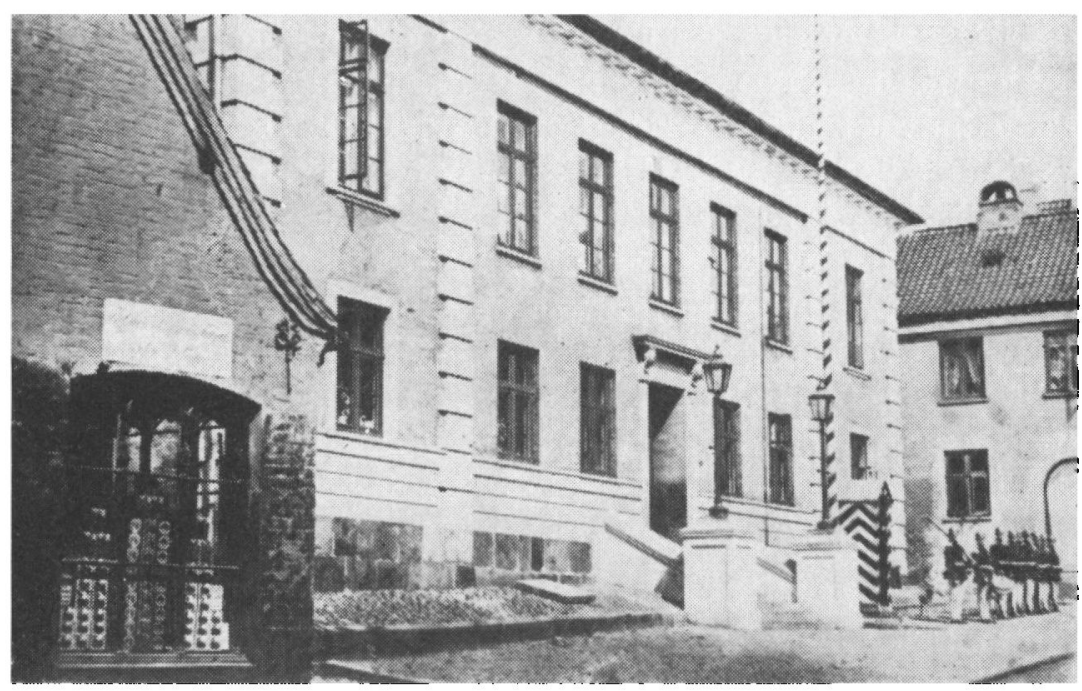

Abenrd radhus omkring 1880. Indtil 1888 var der militarforlagning pá rảdhuset, og fotogrufiet md derfor stamme fra for dette àr.

af C. F. Hansens bygningsværker skulle pudses med mørtel af brunlig-grålig farve.

C. F. Hansens forslag nr. 2 er således ualmindelig klart opbygget efter tidens klassiske mønster med lodret tredeling og vandret todeling. Åbenrå ville have haft en bygning af høj kunstværdi, hvis dette forslag var blevet udfort.

3: Den 10. juli 1827 afleverede C. F. Hansen sine to forslag, ledsaget af følgende bemærkninger: Han ville ikke nægte, at han havde foretrukket façaden på Meyers rids B, men havde alligevel omarbejdet den, fordi han forneden $\emptyset$ nskede en lavere etageh $\varnothing j d e$, således som det fremgik af begge hans forslag. Han gjorde samtidig opmærksom på, at façaden på hans forslag nr. 2 bar mere præg af en offentlig bygning. Man behøvede ikke at frygte, at den $\phi$ gede dekoration ville fordyre byggeriet nævneværdigt, da man sparede ved den ringere $h \phi j d e$. Det vigtigste var de rette proportioner (»Das Meiste hat seinen Grund in den richtigen Verhältnissen «) hævdede han og giver dermed $i$ virkeligheden n $\emptyset \mathrm{g}$ len til den rette forståejse af sin arkitektur.

Da Åbenrå magistrat den 24. august 1827 havde C. F. Hansens 
forslag til behandling, var den straks begejstret, fordi han havde anbragt to vinduer mere $i$ hver etage. Den fandt også, at hans forslag $\mathrm{nr}$. 2 viste en selegantere byggestil, og den anerkendte, at den mere bar præg af at tilhøre en offentlig bygning, men der var alligevel forskelligt at indvende imod hans forslag. Hverken vinduer eller hovedd $6 \mathrm{r}$ fra $\gg$ Frederikslyst « ville kunne finde anvendelse, og desuden havde Peter Callesen ment, at de fem meget h $\phi j e$ vinduer i midterpartiets $\phi$ verste stokvark ville g $\phi$ re muren mindre solid. Trykket på midten ville blive for stærkt. Udgifterne ville også blive for store. Callesen havde anslået dem til at andrage $9112 \mathrm{rbdl}$. for forslag $\mathrm{nr} .1 \mathrm{og} 9989^{3 / 5} \mathrm{rbdl}$. for forslag $\mathrm{nr} .2$.

Noget helt andet var, at den indre rumfordeling var langt bedre i C. F. Hansens forslag nr. 2. I forslag nr. 1 havde han $n \varnothing j$ fulgt den indre fordeling af rummene i Meyers rids, men i sit forslag nr. 2 havde han handlet på egen hånd. I stueetagen var der skabt en bredere korridor, ud til hvilken samtlige indgange til fængsler og borgervagtstue gik, ligesom udgangen til fængselsgården var anbragt lige over for hovedindgangen. Fangevogterens soveværelse, der på Meyers rids havde ligget lige op til fængslet, flyttede C. F. Hansen fremad, hvorved hele arrestforvarerens lejlighed samledes $i$ rådhusets sydlige ende. Fængselscellerne anbragtes mod vest ud mod gården, tre til højre for trappen og et til venstre.

Trappen var langt at foretrække for den på Meyers rids, der havde af rundede trin, fordi det var trappen fra $\gg$ Frederikslyst der skulle anvendes. Fængslerne var mere rummelige, og $\mathrm{k} \not \mathrm{k}$ kenet havde en bedre beliggenhed ud til gården. Hvad man fandt allerbedst ved $C$. F. Hansens forslag nr. 2, var imidlertid rådhussalens placering på 1. sal bag ved midterpartiets fem vinduer ud til gaden. Enden på forhandlingerne blev derfor, at man фnskede bygningens indre indretning efter C. F. Hansens forslag nr. 2, men til façade gnskede man Meyers rids B, dog med det forbehold, at der kom to vinduer mere i hvert stokvark.

Nu gik der en rum tid, hvor magistraten intet horte til byggeplanens videre skæbne hos de forskellige $\emptyset$ vrighedsinstanser. Den 5. december 1827 måtte den rykke for en godkendelse af den trufne beslutning, da man skulle have materialer indk $\phi b t$. 


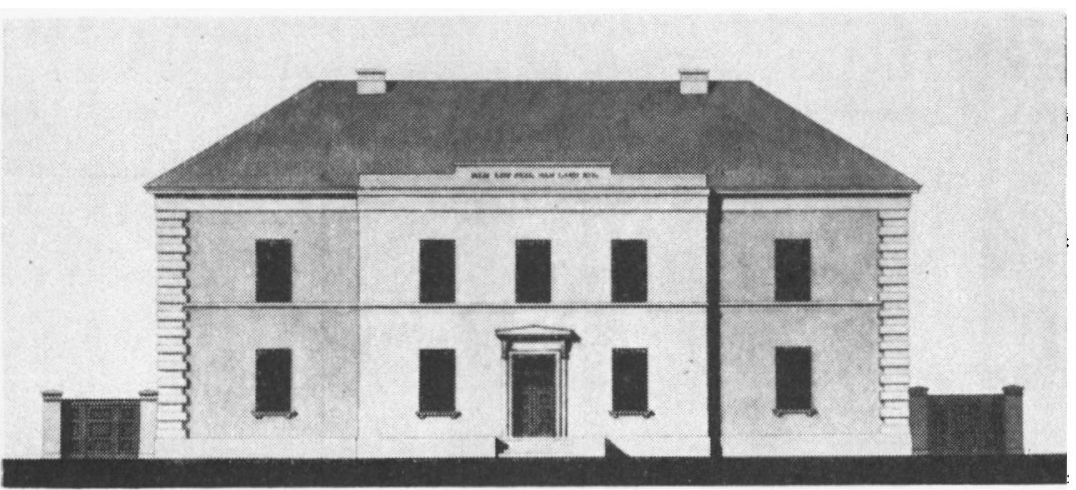

W. F. Meyers rids A ( 48 alen bred).

Forst den 16. februar 1828 kom der atter gang i planerne, idet C. F. Hansen da afgav svar på magistratsbeslutningen af 24. august 1827. Han afviste heri blankt magistratens (eller rettere Peter Callesens) betænkeligheder med hensyn til bygningens holdbarhed i tilfælde af byggeri efter forslag nr. 2. »Ingen sagkyndig vil anse halveirklede buevinduer, der er ordentligt onnnurede, for svagere end sadvanlige firkantede vinduer, især da ikke, når sidepartierne danner en solid modvagt «.

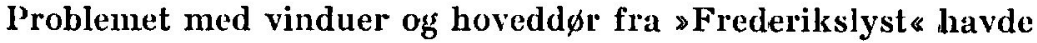
C.F. Hansen af gode grunde ikke haft nogen anelse om, men ikke desto mindre slog han endnu et slag for sit forslag nr. 2. Udsmykningen måtte ikke virke afskrækkende, hvis man ønskede, at rådhusets façade skulle afvige fra et sædvanligt beboelseshus, skrev han. Vinduerne fra $\gg$ Frederikslyst kunne jo anvendes på de tre andre sider, og døren anbringes indvendigt. Trappen fra badeetablissementet ville han derimod under ingen omstandigheder tilråde at bruge. Med sine afrundede trin ville den slet ikke lunne anbringes efter hans forslag nr. 2.

Callesens overslag fandt C. F. Hansen alt for overfladiske, idet detaljer af enhver art savnedes. Skønt Meyers riás A var een alen højere og $41 / 2$ alen bredere, havde Callesen alligevel beregnel, at der ville blive brugt 50.000 mursten farre til dette end til at byggeri efter C. F. Hansens forslag. Overbygningsdirektøren hævdede derfor, at hans forslag ville blive adskilligt billigere at 
udføre end anslået af den åbenråske bygimester og udnyttede lcjligheden til et angreb på den store vilkårlighed som følge af den dobbelte entreprise, der $i$ virkeligheden var tale om, idet Callesen først forestod nedbrydningen af de pågxldende ejendomme og lod dem taksere af sig selv, hvorefter han skulle foretage indk $\phi$ bet af nye materialer og selv lave et nyt overslay over omkostningerne. En offentlig licitation havde været det eneste rigtige, men da magistraten »så tillidsfuldt $\ll$ havde bundet sig til Callesen, sluttede C. F. Hansen med at anbefale, at man holdt sig til ham og appellerede til hans »så højt priste retskaffenhed og kundskaber «.

Da der ingen udvej syntes for forslag $\mathrm{nr}$. 2, foreslog han, at man fjernede »den arkitektoniske udsmykning " på dette forslag, således at façaden fik vinduerne og hoveddoren fra $\gg$ Frederikslyst «. Vinduerne i stueetagen skulle dog afkortes med de underste ruder. Han vedlagde et forslag nr. 3, der ikke mere synes at være bevaret, men det er der kun ringe grund til at beklage, da det var dette, der blev fulgt ved opførelsen af Ảbenrå rådhus.

Omend Åbenrå ved forkastelsen af C. F. Hansens forslag nr. 2 gik glip af et stykke arkitektur, der på fortrinlig måde kunne have tjent til at illustrere vor hjemlige nyklassicisme, er der trods alt kun grund til tilfredshed med den løsning, som de lange forhandlinger om byggeriet fik. Stilmæssigt harmonerer det nuværende rådhus, sådan som det har stået siden indvielsen på dronning Maries fødselsdag den 28. oktober 1830, på en stilfærdig, men tillige værdig måde med det åbenråske k $\phi b s t a d s-$ miljø. Det vidner på en god måde for efterslægten om borgerskabets nøjsomhed og sans for nøgternhed i empiretiden.

Henvisninger: Fremstillingen bygger på materiale i RA., pk. TKIA. D 62 I, hvor de fire her afbildede arkitektforslag af façaden, samt desuden af den indre rumfordeling, findes. Af den $\emptyset$ vrige litteratur om Ảbenrå rådhus kan anføres: Carl E. Johnsen (Emil Ruge) : Aabenraa Raadhus (Vor Hjemstavn, s. 159-167), hvori de фkonomiske forhold i forbindelse med byggeriet særligt omtales, og Knud Voss: Empirens danske rådhuse (Arkitekten, ugehefte, 1954, s. 279), hvor C. F. Hansens autorskab for første gang er påvist, idet der $i$ en forestilling til kongen i 1828 anf $\varnothing$ res: ,Conferentzrath Hansen hat den Riss entworfen. Om sFrederikslyste: Carl E. Johnsen (Emil Ruge) : Badeetablissementet Frederikslyste ved Aabenraa (Sprogforeningens Almanak 1934, s. 40-61). 